\title{
Political Relevance and Corporate Social Responsibility from a Strategic Perspective
}

\author{
Huihui Wang ${ }^{\mathrm{a}}$, Lan Guo ${ }^{\text {b,* }}$ \\ Department of Management, Sichuan University of Science \& Engineering, China \\ a1366835837@qq.com, ${ }^{b}$ 36250520@qq.com \\ ${ }^{*}$ Corresponding author
}

Keywords: strategic perspective, political connection, corporate social responsibility, corporate behavior.

\begin{abstract}
Political connection and corporate social responsibility are important social resources of enterprises, which play an important role in debt financing, corporate governance, corporate performance, R\&D investment and so on. With the research on the potential motive of social responsibility fulfillment, it is found that enterprises with political connections are required to fulfill more social responsibility. There are few literatures on the relationship between political connections and social responsibility. Therefore, based on resource dependence theory and strategic social responsibility concept, this paper combs the relationship between the construction of political ties and the fulfillment of corporate social responsibility, and considers the relationship from the external institutional environment, the nature of corporate property rights, the categories and levels of political connections.
\end{abstract}

\section{Introduction}

The contradiction between the imperfect legal mechanism of our country and the increasingly sound market economic system makes the enterprises to safeguard their own interests through the political connection, while Faccio (2006) finds that political association can not only resolve contradictions but also bring benefits to the company. Responding to natural disasters is the responsibility of the relevant government departments, but with the frequent global natural disasters in recent years, the government cannot fully solve the consequences of natural disasters, more and more companies to help Governments to respond to the crisis through donations. The case of the Wenchuan earthquake in 2008 has made our enterprises realize the importance of political connection, and more and more enterprises have fulfilled their social responsibilities through charitable donation. They found that political association can reduce the risk of loss of enterprises and improve the acquisition capacity of key resources (Muller and whiteman,2008; Jia, Zhang, 2010), and make enthusiastic public interest and self-tax behavior, not only set up a good publicity image and increase the government's impression of enterprises, At this time the enterprise's charitable donation is "social". Lu (2002), Jia and Zhang (2010) found that companies that had political connections when their political connections were expected to have a higher value were motivated to make charitable donations. Corporate social responsibility through charitable 
donations to achieve mutual benefit between government and enterprises ( $\mathrm{Lu}, 2016)$, entrepreneur as a representative of the enterprise, the political relationship formed by the individual political status of the enterprise performance also has a negligible role. Wanda Group chairman Wang Jianlin as a former government official "into the sea" business, its own political connection in the early stage of entrepreneurship and the company's performance has a significant positive correlation, and then was elected as NPC, CPPCC representatives, the Wanda Group to build this political connection to bring a variety of scarce resources and competitive advantage (Liang and Feng, 2010) Promote the rapid development of Wanda Enterprises. With the concept of "corporate citizenship" changed the former enterprise-centric stakeholder theory, so that shareholders, employees, environment and other stakeholders in a relatively fair state, then the implementation of corporate social responsibility has both "social" and "altruistic."

At present, enterprises mainly in two ways to capture the government to obtain scarce resources and local protection, one: the external government retired personnel (Luo and Huang, 2017), elected NPC or CPPCC representatives, the formation of the nature of enterprise property rights inherent relations (Pan, 2008), relatives Shade ( $\mathrm{Li}$ and Qi, 2009), officials are doing business in the sea (Liang and Feng, 2010) and second: responding positively to the Government's call for social responsibility. The political association behavior has already popularized in the world, our country scholar also never interrupted to its research, in 2004-2016 years our country about the political association research mainly concentrates in the enterprise value or the Enterprise performance (Gan, 2017), It is found that political association can improve social responsibility performance in digging into enterprise's motive of social responsibility, and the fulfillment of social responsibility can also strengthen the relationship between government and enterprises, which affects each other. In the study of the literature of political relevance and social responsibility, it is found that social responsibility and political relevance effect are similar, which have some influence on corporate governance, enterprise performance, research and development investment, debt financing and so on, which seems to be substituted for each other. However, there is no further study on the relationship between the two scholars, most scholars only use the political association as a regulatory variable to study the impact of social responsibility on company executives, staff remuneration, donations, etc. (Li, 2010; Liang, 2010; Peng, 2014). Michael once said: "Only by strategically undertaking corporate social responsibility can the company achieve the greatest positive impact on society and reap the wealth of commercial benefits." Based on this, this paper studies the influence of political association on Enterprise Behavior, social responsibility and social responsibility of political association as intermediate variable from the strategic angle, hoping to help the research of social responsibility fulfillment for political association.

\section{Political Association and Corporate Behavior}

The concept of political relevance was first derived from Fisman (2001) 's investigation of the relationship between the Indonesian company and the Suharto family, with the deepening of the research on the connotation and extension of the political connection, the opinions of scholars at home and abroad are quite different. Johnson and Mitton (2003) believe that the company has a political connection when its major shareholder or executive has close relations with its members, ministers and heads of government; Fan, Wong and Zhang (2007) defined political affiliation as the CEO of the company who worked or worked in the central government, local government or army. In China, companies generally create such ambiguous political connections by hiring incumbent or former government officials (Zhang and Zhang, 2005). With the development of economy and society and the enlargement of enterprise scale, the relationship between government and enterprises has become more and more close, which has been directly connected with the existing 
recessive relationship (employing former or incumbent government officials as corporate executives) to the present (entrepreneur himself is the NPC representative and CPPCC member).

Political association has different connotation under the background of the study of various literatures, and from the definition of political relevance research, the source mode of government-enterprise relationship mainly includes the internal political association ((Luo and Huang,2017), which is caused by the property rights of state-owned enterprises (Pan, Xia and Yu, 2008), Relatives Shade ( $\mathrm{Li}$ and Qi, 2009), their own sea (Liang and Feng, 2010) and so on. Because of the different definition of political association, in choosing the research method, the scholars use the assignment method ( $\mathrm{Du}$, Zeng, and $\mathrm{Du}, 2011$ ), the virtual variable method ( $\mathrm{Wu}, \mathrm{Wu}$ and Liu,2008), the proportional method (Luo and Tang, 2009) to study the political association and Enterprise performance, audit choice, financing restraint and enterprise value. Pan et al (2008), Yiao (2015), Du and Zhou (2010) and other studies confirm that political association as a special mechanism in the enterprise various economic activities (mergers and acquisitions, remuneration, corporate governance, audit, internal controls, etc.) play an important role. In previous years, scholars ' research focus on political association was its influence on enterprise value, and the research conclusions of domestic and foreign scholars presented three different results, that is, political association and Enterprise Performance Positive correlation (Fisman,2001; wiwattanakantang and Bunkanwanicha, 2009;Luo and Huang, 2017), negative correlation (Bertrand,2006;joseph and aggarwal,2007; Wu et al, 2008; Deng and Zeng, 2009), unrelated (Fisman et al.,2006,; Wu et al 2008). The differences between the "Hand of support" and "Hand of plunder" in different regions, the definition and measurement of relevant variables, and the selection of samples have led to the difference of relevant empirical research results, and more interestingly, $\operatorname{Re}(2010)$ found that the political association was positively correlated with the enterprise performance in a certain range, and the negative correlation appeared after the range.

Many studies at home and abroad show that enterprise-business linkage is a valuable resource, and enterprises can obtain financing convenience (Faccio, 2006), increase investment efficiency (Chen and Zhu, 2009), reduce tax (Choi and thum,2009) and so on. In the economic transition period of China, the legal mechanism is relatively not sound enough, enterprises cannot fully through the legal system to protect their due interests, so enterprises try to protect the interests of enterprises through the relationship between the Enterprise (Niu, 2015). In our country, relative to state-owned enterprises, the motive and influence of the establishment of political association of Private Enterprises is more worthy of study, the private enterprises as an important part of China's market economy compared to the state-owned enterprises and the government exists "natural" link, it can only through external government retirees or public officials "into the sea", The change of key executives ' political status establishes the relationship between government and enterprise. In our opinion, the motive of constructing the relationship between the private enterprises is to gain more benefits without damaging the benefits. However, in the empirical study, the conclusions are often inconsistent with our expectations and even the contrary, Faccio et al. (2006), Deng and Zeng (2009), Yu et al. (2010) believe that political association will lead to the decline of private enterprise performance.

A review of the literature on Political association in China in the 2004-2016 found political relevance in corporate value, bank loans, corporate performance, market level, institutional environment, corporate governance, government subsidies, financing constraints, operating performance, overinvestment, corporate performance, corporate social responsibility, research and development inputs, investment efficiency, earnings quality, Social capital, earnings management, diversification, accounting information quality, technological innovation and other aspects of the impact of corporate behavior. Lei et al (2009), Zeng and Deng(2012) believe that the political connection can improve the corporate value in general, especially the political association of Private 
Enterprises has a significant positive effect on enterprise value, and the greater the strength of political association, the higher the value of enterprise (Luo and Huang, 2017). You et al(2010) found that political association hindered the improvement of corporate governance efficiency and reduced the value of the company. For private enterprises, the higher the degree of political association, the worse the business performance, the higher the Political association degree of the actual controller, the worse the Enterprise performance (Deng and Zeng, 2009). This "visible hand" of the government will have the opposite effect on the performance of the Enterprise (Xia and Yang, 2012). Feng,(2011) thinks that the influence of political association on Enterprise performance is different from the problem of variable and sample selection. Therefore, in the study of the relationship between political association and enterprise value, besides the performance index variable should also take into account the internal incentive mechanism and enterprise external governance environment Constraints and regulatory role (Xiong, 2012). Li, Wang and Zhou (2008), Wu et al(2009), Li and Xie(2014) found that political association can make financing facilities for enterprises, and it is very helpful for private enterprises to solve the problem of financing restraint. The reduction of financing constraints can improve the investment efficiency of enterprises, which shows that the promotion of political association is beneficial to the senior executives to make more positive decisions on investment. The choice of the auditors of private enterprises will consider the political correlation factors, in the areas where the government intervenes more and the rule of law is low, politically affiliated enterprises tend to choose the low quality auditors, and the non-politically affiliated enterprises tend to choose high-quality auditors (Lei,2009, Wahab, Zain and Rahman, 2010). Sun et al (2006) pointed out that enterprises with strong political correlation can influence accounting conservatism by reducing the transparency of accounting information. But Du and Zhou (2010) find that the information disclosure of privately listed companies with political connections is less transparent. In the non-state-owned enterprises, the political association of Enterprises promotes the investment of enterprise research and development, and the political connection has a significant effect on the investment of Enterprise research and Development (Tang, 2011 ) in the region with fast marketization process.

In a comprehensive way, the system environment, marketization degree and enterprise nature are the necessary conditions for the study of political association, and it is a universal method to use the assignment method to classify political association. According to the theory of resource dependence and agency cost theory, the influence of political association on Enterprises is negative, in order to make it beneficial to the sustainable development of enterprises, from the strategic perspective, enterprises ' active performance of social responsibility can strengthen political connection and improve reputation.

\section{Social Responsibility Fulfillment and Corporate Behavior}

With the continuous development of economy and society, the responsibility of enterprises as "citizens" has been paid great attention by all circles of society. The concept of corporate social responsibility originated in the United States in the early 20th century of 19th century, Sheldon (1924) found that corporate social responsibility contains moral factors, and that enterprises ' services to the Community contribute to the benefit of the community, and enterprises can consider linking responsibility to society and various responsibilities to meet consumer needs. It is generally accepted that corporate social responsibility refers to the enterprise as one of the members of society, to bear the social responsibility of all its stakeholders, to safeguard the legitimate interests of its stakeholders, and from the political government public responsibility, employee responsibility, shareholder responsibility, environmental responsibility, consumer responsibility, Business partner responsibility and community public responsibility seven aspects discuss the social responsibility 
that the enterprise should fulfill. With the research on corporate social responsibility and corporate financial performance, it is found that corporate social responsibility, like the profitability of enterprises, becomes the basic requirement of sustainable development of enterprises. As a barometer of China's CSR practice, the latest data from the China CSR Index Report 2016 show that state-owned enterprises pay more attention to the implementation of Community, government, environment and other stakeholders; private enterprises perform best for the community, and foreign and Hong Kong and Macao Enterprises pay more attention to corporate social responsibility strategy. Different property rights characteristics of corporate social responsibility implementation of different focus, but the ultimate goal of the enterprises are responsible for the interests of enterprises, and the implementation of social responsibility in the process will increase the cost of enterprises, in order to protect profits greater than the cost of enterprises will be cautious to carry out responsibility behavior. The implementation of CSR can help enterprises to establish political links, and political links can bring key resources to enterprises, both complement each other.

There are many literatures on the relationship between social responsibility and debt financing cost and financing restraint, but the field of social responsibility has been widely recognized in recent years. Chen(2016) believes that corporate social responsibility can enhance communication links with all parties, strengthen and expand social network, and help increase social capital and gain sustainable competitive advantage of enterprises. Yi and Xu (2014) believe that enterprises are subject to social responsibility by the Government and other stakeholders, such as power agencies, customers, suppliers, media, and the public, and that the level of political association and the level of market-oriented development of senior executives have a positive impact on corporate social responsibility. Wang(2013) found that political connections in non-state-owned companies had a positive effect on social responsibility disclosures, and Zhang(2012) found that executives with political connections had a significant role to play in the fulfilment of corporate social responsibility. At present, there are many researches on the issues of political association and corporate social responsibility alone, but there are not many literatures on the correlation between them. The study of Hoogh and Hartog (2008) found that public executives with political connections had a higher expectation of fulfilling their social responsibilities; Lou and Zhang (2014) found that the political affiliated enterprises have a strategic choice in the process of social responsibility; Luo (2015) studies found that There is a positive correlation between political association and the quality of information disclosure of corporate social responsibility. The political connection affects the enterprise public welfare donation and the Commonweal donation as the enterprise fulfills the social responsibility the main way to the enterprise performance to have the Influence (Du et al, 2010). These documents indicate that there is a real connection between political association and social Responsibility, but there is still a lack of literature study on whether political association has influence on the performance of CSR.

\section{Political Relevance, Social Responsibility and Corporate Behavior}

The development of economy has promoted the development of private enterprises, meanwhile, the market competition faced by private enterprises is more and more fierce. China's private enterprises in the development process of the macro-problems are mainly in the following aspects: financing difficulties, investment and operating environment deterioration and tax burden. and the construction of corporate social responsibility and political connections can alleviate these difficulties. The different motives of enterprise behavior lead to the fracture or construction of the relationship between the enterprises and enterprises, and the different corporate strategic choices cause the result of social responsibility fulfillment. In the transition period, there are two main ways to establish the political association: first, the executives of the enterprise to run for the NPC or 
CPPCC members, and the other is to hire outgoing or retired government officials to enter the enterprise. Because of the different positions and levels of officials, the impact of different political connections on firms varies. Lou and Zhang(2014) The empirical results show that the political association on behalf of members can improve shareholder's responsibility, creditor's responsibility and public responsibility, but have no significant influence on government responsibility and employee's responsibility. In China, entrepreneurs elected to the NPC or CPPCC members of their social influence, will lead to corporate behavior is susceptible to mass media, government departments and industry associations, this excessive public attention will often encourage entrepreneurs to pay more attention to their own and corporate image, in order to maintain the good reputation of enterprises and individuals. At this time, although the entrepreneurial ideology has improved, but the corporate social responsibility is not fully "altruistic", mainly due to public pressure. If companies are building political connections with government officials, and because executives who have worked in government departments are now out of the political circle, their communications with the government will be drastically reduced, social pressures and concerns greatly diminished, and social responsibility will be paid at a cost. Naturally motivating them to shape a good corporate image and to promote corporate social responsibility will also be a sharp weakening of the momentum. Therefore, in the initial stage of the enterprise, the social responsibility may be a kind of strategic behavior, rather than the conscious feedback to the society. Luo and Tang (2009) The study found that, as far as social capital is concerned, private enterprises will be more likely to enter government regulation industry and obtain more government subsidy. However, the results of the research on Political association and Enterprise performance are different, and some studies suggest that political association has positive influence on stock price, enterprise value or stock return rate. However, Deng and Zeng (2009) found that the higher the political association degree of private enterprise, the worse the business efficiency, the higher the Political association degree of the actual controller, the worse the business efficiency. Enterprises face the different social responsibility behavior preference of the stakeholders, government and society, but there is a significant positive relationship between fulfilling corporate social responsibility and enterprise sustainable development (Wu and Deng, 2014). In order to improve the sustainable development of enterprises and gain the recognition and respect of stakeholders, this paper studies the relationship between political association and corporate social responsibility based on resource dependence theory, stakeholder theory and sustainable development theory, which affect the sustainable development of enterprises. Li and Xie(2014) research finds that fulfilling social responsibilities helps private companies get loans and can help companies establish political connections. Scholars have tried to verify the relationship between political association and corporate social Responsibility through the question of "whether the political connection of private enterprise and the enterprise social responsibility can bring return", and some scholars believe that the relationship between political association and fulfilling corporate social responsibility is mutually beneficial, and the whole political relation is positively correlated with social responsibility performance (Niu,2015),some scholars believe that corporate social responsibility is an effective means to deal with the risk of change in political environment, and the political affiliated enterprises have strategic choice in the process of undertaking social responsibility (Lou and Zhang,2014). There is no unanimous conclusion on the empirical research of the existing political association and social Responsibility to the enterprise performance. In the context of China's special system, $\mathrm{Lu}(2016)$ studies that there is no political connection and the level of political association to the impact of corporate social responsibility and corporate governance linked. Niu(2015) The study found that the political connection in different regional system environment has the opposite effect on the performance of enterprise and the fulfillment of corporate social responsibility. You et al(2008) through empirical tests, it is found that the change of officials or the 
political connection of executive change can improve the performance of enterprises, and the existence of political association in the case of government intervention will inhibit the development of enterprises. However, Dong and Liu(2016) found that the business performance was not related to the change of executive, and the political relationship was significantly negatively correlated with the change of executive, and the factors of corporate governance were positively correlated with the change of executive. The different research perspectives and research methods make these conclusions different, Xia et al(2017) based on stakeholder theory, from two types of political associations of representatives and government officials, we measure the social responsibility of shareholders, creditors, employees, government and public responsibility in five dimensions, Niu(2015) according to the theory of resource dependence, this paper studies political association and Corporate Social Responsibility, and analyzes the influence of different political connections, different political related levels and institutional environment on the responsibility of the Enterprise Du Society, which has no significant influence on the financial performance of the enterprise, whether the private enterprise has political connection or not.

After 18, the government weakened market controls, which could undermine the impact of political connections on listed companies. Feng (2011) believes that because of its high political reputation and social influence, the representative Committee will actively carry out social responsibility. As for the political association of government officials, because these government officials have now withdrawn from the political circle, the communication with the government, social pressure and so on have been significantly reduced, the motivation to fulfill social responsibility has declined. Zhang et al(2014) based on the data of listed companies in China's chemical industry, the influence of political association on financial performance is examined, and it is found that the political association of representative Committee can improve the financial performance of the enterprise, thus better fulfill the social responsibility, and the political association of government officials reduces the financial performance of the enterprise. and the impact on corporate social responsibility is not significant. Kong and $\mathrm{Li}(2015)$ based on the data of listed companies in the food and beverage industry, this paper studies the influence of political association on Corporate Social Responsibility, and discovers that political association can effectively promote the exercise of social responsibility of listed companies in beverage industry, and then improve the financial performance of the company, and there is a high positive correlation between them. Peng and Ni(2014) based on the panel data of the listed companies in the high-end equipment manufacturing industry, the influence of political association on Corporate Social Responsibility is examined from the perspective of internal governance, and the social responsibility of the enterprise is affected by the influence of equity concentration, independent Director, supervisory board size and executive compensation. In general, there is a positive impact on corporate social responsibility. Gao an Yang(2015) The relationship between political association, social Responsibility and enterprise performance is studied, and it is found that political association can promote the growth of enterprise performance by promoting social responsibility. These results show that in the economic transition period, the establishment of political connection is the choice of corporate political strategy, enterprises to fulfill social responsibility will be affected by the political relationship, and the initiative of enterprises to take social responsibility is not completely "altruistic".

\section{Review and Prospect of Research}

To sum up, it is necessary to consider the influence of political association in the study of corporate social responsibility behavior motivation. In the past, when political association and corporate Social Responsibility were studied, the relationship between them was often fragmented. 
In this paper, the author finds that scholars pay more attention to the influence of political association and social Responsibility on corporate finance, such as tax, financing, rent-seeking cost, agency cost and so on, and the effect of political association on Enterprise performance has not been unified conclusion. The influence of social responsibility and political connection on enterprise behavior is similar, based on the principle of reciprocity; enterprises may actively fulfill their social responsibilities in order to strengthen their ties with the government. From the strategic point of view, the political association and social Responsibility are the enterprise's "double-edged sword" can not only bring benefits to the enterprise can also become a corporate profit burden. In order to make the enterprise sustainable development, it is necessary to study the internal connection between political association and corporate social Responsibility, to find out the latent motive of the enterprise to fulfill social responsibility, to avoid the passive performance of social responsibility, and to cause the dissatisfaction of the government and other stakeholders, which leads to the weakening or rupture of this political connection. The paper thinks that the existing research will only consider the influence of the two to the enterprise from the static level, and in the future research, we can consider the research on the influence of the political association to the enterprise social responsibility fulfillment, and strengthen its depth and breadth.

\section{Acknowledgements}

Fund project: National Social Science Fund Western Project "Research on the nesting mechanism of government behavior and corporate social responsibility" (15XGL009).

\section{References}

[1] Du, X.Q., Q. Zeng., and Y.Q. Du. Do Political Connections Curb R\&D Investment of Chinese Listed Firms? [J]. Financial Research,2011(08):93-110.

[2] Faccio, M., Masulis. R. W., Mc-Connell, J.J. Political Connections and Corporate Bailouts[J]. Journal of Finance, 2006, 61: 2597-2635.

[3] Yu, M.G, H.B. Pan., The Relationship between Politics, Institutional Environments and Private Enterprises' Access to Bank Loans [J]. Management World,2008,(8):9-21.

[4] Luo, D.L., X.L, Liu., Political relations, barriers to entry and corporate performance--empirical evidence from private listed companies in China [J]. Management World,2009(05):97-106.

[5] Wu, W.F., C.F. Wu., and M. Rui. The political background and tax preference of Chinese listed company executives [J]. Management World, 2009,(3):134-142.

[6] Luo, D.L., Q.Q. Tang. Political relations, social capital and access to policy resources: Empirical evidence from private listed companies in China [J]. The Journal of World Economy.2009,(7):84-96.

[7] Fisman, Raymond, Estimating the Value of Political Connections[J]. American Economic Review, 2001,91(4):1095-1102.

[8] Luo, D.L., Q.Y. Huang. Executives with Professional Background and Financing Cost of Quasi-municipal Corporate Bonds_Empirical Research Based on City-level and County-level Quasi-municipal Companies [J]. Research of Finance and Accounting,2017(06):62-69.

[9] Deng. J.P., Y. Zeng. Can Political Improve the Performance of Private Enterprises[J]. China Industrial Economics.2009,(2):98-108.

[10] Fan, Wang, Zhang. Politically-connected CEOs, Corporate Govermance and Post-IPO Performance of China Partially Privatized Firms [J]. Journal of Financial Economics, 2007,84(2):330-357.

[11] Faccio M. Politically Connected Firms[J]. American Economic Review, 2007,96(1):369-386.

[12] Zhang. C., Z.K. Lou., and B. Zhan. Political Connection, Financial Performance and Corporate Social Responsibility_Evidence From Listed Companies of the Chemical Industry in China[J]. Management Review, 2014,26(01):130-139.

[13] Guo. L., F. He. Industry Competition,Firm Competitive Position and Social Responsibility: An Empirical Examination of Chinese Alcohol Industry [J]. Modern Finance and Economics-Journal of Tianjin University of Finance and Economics, 2016, 3:62 - 72.

[14] Porter, M E, and Kramer, M R. Strategy and society: The link between competitive advantage and corporate social 
responsibility Harvard Business Review. Vol 39( 44), 2006.

[15] Jia. M., Z. Zhang. Does Political Connection Influence Corporate Philanthropy? [J]. Management World, 2010,(4):99-113 .

[16] Li. S., X.Y. Xie. Corporate Social Responsibility, Political Relationship and Debt Financing of Private Enterprises: Evidence from Chinese Capital Market[J]. Nankai Business Review.2014,(6):30-40.

[17] Lou, Z.k., C. Zhang., Political Connections and Social Responsibility: Consciously Feedback or Strategic Choice [J]. Economy and Management,2014,28(2):66-71.

[18] Zhu Congcong.Achievement demand, political connection and corporate social responsibility fulfillment [D]. Zhejiang University Of Finance \& Economics,2015.

[19] Yao Ningfeng. Political connection, corporate governance and corporate social responsibility [D]. Zhejiang University Of Finance \& Economics,2015.

[20] Yang. Q.L, Y.F. Zhang., R.T. Yuan. Corporate Social Responsibility, Political Linkage and Debt Financing[J]. Journal of Nanhua University (Social Science Edition). 2017,(1):63-68.

[21] Xia. B.Y, Y.M. Lu., H.F. Peng. The influence of political association on the heterogeneity of CSR behavior--a case study of listed companies in Jiangsu Province [J]. Finance and Accounting Monthly.2017,(11):38-43.

[22] Guo, L., Z.Q. Su. Local Protection, Political Connection and the Corporate Social Responsibility-Evidence from Listed Companies of Alcohol Industry[J].China Soft Science.2017,(6):110-114.

[23] Niu Xiaoyan. Research on the Influence of Political Connections on Firm's Financial Performance and Social Responsibility [D]. Shandong University,2015. 